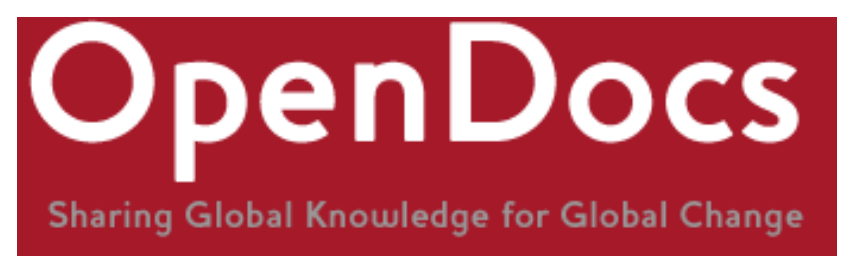

Title: Negotiating New Relationships: How the Ethiopian State is Involving China and Brazil in Agriculture and Rural Development

Citation: Alemu, D. and Scoones, I. (2013). Negotiating New Relationships: How the Ethiopian State is Involving China and Brazil in Agriculture and Rural Development. IDS Bulletin, 44.4

Official URL: http://onlinelibrary.wiley.com/journal/10.1111/(ISSN)1759-5436

More details/abstract: This article provides an overview of Brazilian and Chinese agricultural development cooperation activities in Ethiopia. In the context of a highly aiddependent country, the Government of Ethiopia (GoE) has developed an effective way of balancing donor inputs, both regionally and sectorally. Development cooperation is carefully managed and coordinated, in line with the national 'Growth and Transformation Plan'. The government promotes harmonisation and an alignment process of western donor support through the Ethiopian High Level Forum, with five subsidiary sector-specific working groups. Brazil and China are currently not engaged in these coordination platforms working instead on a bilateral basis. Core activities include experience sharing in public governance, technical cooperation, and the attraction of private and public investments. In the case of Brazil, the cooperation focuses on renewable energy sector development mainly related to biofuels derived from sugarcane production, whilst in the case of China, cooperation is more focused on infrastructure, agricultural technology and skill transfer. The approach adopted by Ethiopia reflects a commitment to a 'developmental state' approach. This seems to be delivering results in the agricultural sector, and beyond.

Version: Submitted version

Terms of use: This work has been licensed by the copyright holder for distribution in electronic format via any medium for the lifetime of the OpenDocs repository for the purpose of free access without charge. The definitive version is available at http://onlinelibrary.wiley.com/journal/10.1111/(ISSN)1759-5436

This is a download from OpenDocs at the Institute of Development Studies

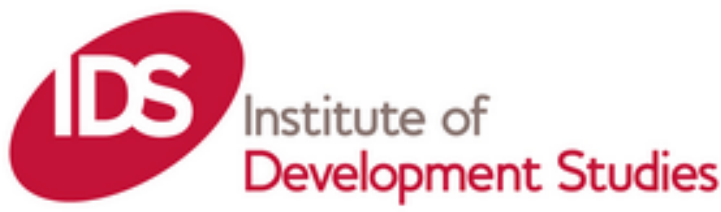


This is a pre-print version of this article. How to cite:

Alemu, D. and Scoones, I. (2013). Negotiating New Relationships: How the Ethiopian State is Involving China and Brazil in Agriculture and Rural Development. IDS Bulletin, 44.4

http://onlinelibrary.wiley.com/journal/10.1111/(ISSN)1759-5436/issues

\title{
Negotiating New Relationships: How the Ethiopian State is Involving China and Brazil in Agriculture and Rural Development
}

\author{
Dawit Alemu and Ian Scoones
}

\begin{abstract}
This article provides an overview of Brazilian and Chinese agricultural development cooperation activities in Ethiopia. In the context of a highly aid-dependent country, the Government of Ethiopia (GoE) has developed an effective way of balancing donor inputs, both regionally and sectorally. Development cooperation is carefully managed and coordinated, in line with the national 'Growth and Transformation Plan.' The government promotes harmonisation and an alignment process of western donor support through the Ethiopian High Level Forum, with five subsidiary sector-specific working groups. Brazil and China are currently not engaged in these coordination platforms working instead on a bilateral basis. Core activities include experience sharing in public governance, technical cooperation, and the attraction of private and public investments. In the case of Brazil, the cooperation focuses on renewable energy sector development mainly related to biofuels derived from sugarcane production, whilst in the case of China, cooperation is more focused on infrastructure, agricultural technology and skill transfer. The approach adopted by Ethiopia reflects a commitment to a 'developmental state' approach. This seems to be delivering results in the agricultural sector, and beyond.
\end{abstract}

\section{Introduction}

Ethiopia is a poor country, highly reliant on external donor aid. In 2010 the percentage of GDP made up of aid was 11 per cent of its Gross National Income. ${ }^{1}$ Yet Ethiopia is a country with ambitions, particularly in the agricultural field which accounted for a significant 41.1 per cent of GDP in 2010/11 fiscal year (NBE 2011). And with economic growth rates being some of the highest in the world in the last few years, peaking at 11.4 per cent in 2010/11, ${ }^{2}$ such ambitions are beginning to be realised, with agriculture pivotal to the story (Geiger and Goh 2012).

The now late Prime Minister, Meles Zenawi, was at the centre of this vision, being deeply committed to a development revolution in the country. While dependent on donors, Ethiopia is not just a passive recipient. Prime Minister Meles in particular was highly adept at presenting Ethiopia's case, but also providing a framework for investment and aid which was on Ethiopia's terms. An East Asian developmental state vision, modelled on Korea and Japan, has been promulgated which combines tight state control with the encouragement of investment (Mkandawire 2001). 
In this context, the importance of South-South cooperation has been increasing through increased official engagement of the Ethiopian government with governments and private sector actors in the South. China in particular has been seen as an important model in recent years. This article gives an overview of such cooperation, focusing on the engagements of China and Brazil in agricultural development. Different types of engagement are discussed, including experience sharing in public governance, technical cooperation, and the attraction of private and public investments.

\section{State agency: Negotiating external relationships}

In the terms of the debate on state power and capacity in Africa, the Ethiopian state has 'agency', and is able to negotiate with powerful external actors for its own ends, avoiding the position of being a passive 'recipient' or a 'pawn' in wider power games (Mohan and Lampert 2013; Brown 2012; Mohan and Power 2008). With limited resources itself its room for manoeuvre is clearly constrained, but state officials have been able to negotiate good terms and coordinate aid efforts in ways absent in many other African countries. This has largely been developed in relation to the conventional western donor agencies, but new development cooperation partners, such as China and Brazil, do not simply get their own way in Ethiopia.

This relative effectiveness in managing external aid and investment towards national ends is the result of a number of ways 'state agency' is cultivated and influenced. It is facilitated by a tightly controlled state apparatus, often associated with the leaders of a governing political party that captures rents centrally, but also distributes them for developmental gains (Kelsall 2013). This strategy is often associated with strong state enterprises and politically-controlled businesses which help structure and support economic activity. In Ethiopia, perhaps unlike other countries where structural adjustment demolished the state sector, there still are a large number of state enterprises which act to guide economic activity in key sectors, as well as the quasi-private 'endowment companies' which retain strong party involvement (Vaughan and Gebremichael 2011; Altenberg 2010). These companies are also becoming promoters of the South-South cooperation through different business arrangements.

This developmental mode, Kelsall argues, exists in Africa in those countries where economic growth and poverty reduction has been most successful, including perhaps particularly Ethiopia, but also Rwanda, Ghana and, to some degree, Tanzania. This does not necessarily conform to the 'good governance' agendas of the western donors, and sometimes is associated with undemocratic practices, even human rights abuses. But, Kelsall argues, while such issues need challenging, the developmental successes cannot be ignored either. Such an approach that 'works with the grain' of African politics (Booth 2011) is one that needs serious consideration if a pragmatic approach to African development is to be achieved.

So, what are the elements of Ethiopia's positioning, and consequent development success? And how has this been related to the engagement with China and Brazil in agricultural development? Four themes are identified. First, Ethiopia occupies a particular position in regional geopolitics, and this can be used to its advantage. Located between countries regarded as a potential threat to the west - such as Sudan and Somalia - Ethiopia has carefully positioned itself as a friend of the west, and the US in particular. With such strategic credentials, Ethiopia has perhaps more bargaining power in development cooperation negotiations compared to many other African countries.

Second was the extraordinary effectiveness of Prime Minister Meles. Emerging from a Maoist-inspired guerrilla struggle and having studied for several degrees in the west, he was equally comfortable engaging in the discourse of South-South solidarity and anti-colonialism with Chinese party leaders, as he was with western leaders as a special invitee at G8 meetings. He worked closely with Tony Blair for example on the Africa Commission, and was feted by successive US administrations, Bill Gates and many others. His 
formidable intellect and superb diplomatic skills allowed him to move easily between different discursive frames and political spaces, but always with an eye on his own objectives.

Third is the considerable bureaucratic capacity of the Ethiopian state, despite its limited resources. Ethiopia does not just wait for donors to suggest something, and allow them to get on with it; the government always has a plan. This may exist in multiple forms, with public and private versions (often in different languages and scripts), but external players are expected to be respectful and compliant. Using the rhetoric of aid effectiveness, and deploying the routines and procedures of the aid business, donors are channelled, coordinated and carefully controlled. Much the same happens with investors who must comply with the procedures of the Ethiopian Investment Agency and respective sectoral ministries which, following international best practice, logs all investments on a public database. Of course this does not apply to everyone, and there are a few who, given their political connections and their considerable contributions to the national economy, are given some leeway and concessions. Tight political oversight of bureaucratic systems allows careful control, and pragmatic discretion if the conditions require.

Finally, Ethiopia's long associations with the Non-Aligned Movement, and as a leader in the African Union and host of its impressive new headquarters, means that the rhetoric of South-South cooperation is central to Ethiopia's positioning. But again it takes a pragmatic stance, recognising the importance of western aid flows it has carefully avoided any antagonism. The isolation of the previous military socialist Derg regime, tied so tightly to the fortunes of the Soviet Union, and collapsing with it, is a lesson for any Ethiopian leader. Persistence of poverty and food insecurity are seen as major threats and sources of conflict, and therefore addressing them through agriculture is the top political priority. Thus a plural approach, cultivating multiple friends for multiple sources of support has been essential. This again has been implemented in a typically thorough and pragmatic way. Senior state and party officials are encouraged to study and build their capacities to understand the aid and investment system. Knowing how to speak the donors' language is essential if you are to respond to and manipulate the system to your own advantage. Study leave breaks, exchange visits and on-the-job training is encouraged, even for the very highest officials. This means that they are kept abreast of the fast-changing, often very fickle and faddish world of development aid. As the new 'rising powers' have come on the scene, this has been replicated, and numerous Ethiopian officials have been to China and India (and slightly fewer to Brazil) to learn how things are done, and how such ideas and practices can be translated into the Ethiopian context.

\section{Agriculture and rural development cooperation in Ethiopia}

How then have these features of Ethiopian state agency and a vision of a 'developmental state' been translated in the field of agriculture and rural development, and in particular the new engagements by China and Brazil?

At the centre of the Ethiopian state's vision for the future is the Growth and Transformation Plan, running to 2015. This envisages a rapid transformation of agriculture, with substantial external investment, including new large-scale commercial farming operations, and supported by major improvements in market systems and infrastructure (MoFED 2010). While the centrality of smallholder production is recognised and expected to continue as the core of the agricultural sector, Ethiopia has been courting external investments in agriculture. Starting with investments in floriculture in the area around the capital, Addis Ababa, this trend has increased to include major land leases in areas such as Gambella and Beneshangul, where agricultural potential is high, and land pressure is relatively low. This has brought controversy, as such investors have been cast as 'land grabbers', undermining local livelihoods, and precipitating resettlement, yet more generally such interventions, as with other forms of investor engagement, need to be seen in the Ethiopian context as part of a wider strategy of state mediated control of investment (Lavers 2012a, b). 
In general, the Ethiopian government cooperation with donor countries emanates from the joint donor principles of the Global Donor Platform for Rural Development (GDPRD 2009). The Government has established a structure to support the harmonisation and alignment process of donor support. This is called the Ethiopian High Level Forum, established in June 2003 with the associated nine subsidiary joint sector working groups - namely Health, Education, Rural Development, Roads, Water, Public Financial Management, Gender, HIV/AIDS, and Public Sector Capacity Building (MoFED 2005).

The government-donor coordination platform for agriculture, natural resource management and food security, called the Rural Economic Development and Food Security Sector Working Group (RED\&FS SWG), was formally established in the country in April 2008 consisting of representatives from government offices and donors. Its objective is jointly to review sector level implementation status and coordinate and harmonise efforts of various development partners supporting thematic areas under RED \& FS. It is composed of an Executive Committee and three Technical Committees (Agricultural Growth; Sustainable Land Management; and Disaster Risk Management and Food Security) (MoA 2013).

Members of the RED\&FS SWG include western donors, technical assistance agencies and embassies of western countries. Under the RED\&FS SWG, these development partners are aligned in supporting five national programmes: (i) Agricultural Growth Programme (AGP); (ii) Sustainable Land Management Programme (SLMP); (iii) Productive Safety Net Programme (PSNP); (iv) Households' Asset Building Programme (HAB); (v) Disaster Risk Management and Food Security Program (DRMFS).

Brazil and China are not engaged in the RED\&FS platform, nor are they part of the development partners' supported programmes. The engagement of Brazil and China as development partners in Ethiopia is bilateral, mainly in the form of experience sharing in public governance, technical cooperation, and attraction of private and public investments. In order to strengthen this bilateral relationship, there is a unique institutional arrangement in the different public organisations, especially for China.

\section{Promoting collaboration with Brazil and China}

In terms of the institutional set-up in promoting government-to-government collaboration, the different organs within the Ministry of Finance and Economic Development (MoFED) and Ministry of Foreign Affairs (MoFA) play an important role in promoting the collaboration with Brazil and China.

Due to the emphasis given for strengthened collaboration with China, the MoFED has an independent office dealing only with China, which is called the Ethio-China Development Co-operation Office. This is in addition to the International Financial Co-operation Directorate and the Bilateral Cooperation Directorate that also plays a key role in promoting collaboration. The official justification for this emphasis is related to the public belief that the relationship with China has provided, and is expected to provide, the country with economic development; the perception that China's policies are based on the principles of promoting mutual advantage and a serious commitment to a win-win scenario in bilateral relations; and China's understanding of Ethiopia's need to own its own economic development strategy. China provides soft and interest free loans as well as grants for development projects without any conditions. As a balance to the many strings attached to Western development aid, heightened especially since the contested elections of 2005, China's contribution is an important part of the overall portfolio.

In addition, the Economy and Business Directorate of MoFA, in collaboration with Ethiopian Missions in Brazil and China and the Ethiopian Investment Agency, promote collaboration mainly in terms of identifying sources of Foreign Direct Investment. This involves the selection of appropriate investors, analysing data on assistance, loans and technical cooperation agreements, providing information on 
government priorities and identifying partners to finance priority areas as appropriate, and investigating development assistance experience and trends of bilateral and multilateral foreign assistance. Similarly, the Americas Affairs and the Asia and Oceania Affairs Directorates of the MoFA are also involved in promoting priority areas for political and economic cooperation with Brazil and China by conducting studies in areas of trade, investment, development cooperation, and technical assistance.

This very active approach to trade and investment promotion certainly pays off. The floriculture sector, for example, has grown from US\$2 million worth of exports to US\$170 million between 2003 and 2010, involving 85 companies, three-quarters of which are foreign. Ethiopia is now the second largest exporter of cut roses in Africa, and the sixth largest in the world (Kelsall 2013: 108). Land has been offered, concessions on export arrangements guaranteed, and a fast-track investment approach encouraged through the establishment of the Ethiopian Horticulture Agency, all with direct facilitation by the state, and often with directed political oversight from the Prime Minster himself (Gebreyesus and Lizuka 2010; Altenberg 2010). And in the field of agricultural investment in general, the rising powers - including China and Brazil - are expected to play a major role.

\section{Engagement of Brazil and China as development partners in Ethiopia}

Engagements between Ethiopia and Brazil and China are occurring on three broad fronts: experiencesharing and bench marking of public organisations, as part of public sector reform; technical cooperation in a range of areas; and private investment in agriculture. The existing cases are discussed below. Each shows how 'state agency' influences external relations to realise a 'developmental state' vision through such cooperation arrangements.

\subsection{Experience sharing in public governance}

Experience sharing is promoted in the form of bench-marking best practices of public governance from countries in the South through experience sharing tours of higher officials, and invitations of experts from the South. Ethiopia has been keen to learn from countries that have achieved major economic growth through the 'developmental state' approach (or variants of), with the political leadership being unconvinced by the neoliberal economic reform edicts of the West (although of course paying due abeyance to them at key points).

Ethiopian public institutions have been bench-marking a number of countries in the South, mainly China, India, Thailand and Brazil. The key assumptions considered for bench-marking these countries were: they have witnessed fast economic growth; they have more or less similar administration, such as a federal state system (India, Brazil etc); and, through the engagement, there would be a possibility of accessing their markets through trade agreements, facilitated through ties established between state officials of the respective countries.

At least one bench-marking visit has been made by each public organisation, involving higher officials to the rank of Ministers, State Ministers, Directors and Senior Experts. In general, the visits are coordinated by Ethiopian diplomatic missions in the respective countries. The key mechanism of bench-marking is through experience sharing visits. Below are some examples of bench-marked experiences that have been adapted in Ethiopia in the agricultural sector:

(i) Restructuring the Ethiopian Agricultural Research System based on the Indian system. Key issues in bench-marking were: (a) the institutional setup to manage a decentralised agricultural research system where there are national research programmes and regional/state research programmes; 
(b) the approaches in research programme design, implementation and budgeting; and (c) the approach in agricultural research and subsequent development linkages.

(ii) The promotion of a bio-energy strategy based on the Brazilian strategy. The biofuel sector development in Brazil is considered as a model. The key justification of biofuel sector development is to reduce full dependence on petroleum imports with a target of 25 per cent ethanol blending by 2015 from the current 5 per cent.

(iii) The promotion of agricultural technical vocational education and training (TVET) adapted from China. This has been made through the contributions of China to the construction of vocational, technical and training colleges in various parts of the country and numerous volunteer trainers and teachers at different levels.

(iv) Promoting the idea of agro-industry zones nearby major towns adapted from China. This intervention has been bench-marked through the frequent exchange of visits by high level officials and legislators.

(v) Adaptation of group action approaches from China and Korea resulting in the organisation of farmers into groups, an approach which has been underway since late 2011.

\subsection{Technical cooperation}

Technical cooperation in the form of bilateral agreements is an approach followed by both China and Brazil in support of the agricultural development efforts in Ethiopia.

The technical cooperation between Ethiopia and Brazil is yet to be cemented and developed, although an all-round agreement of cooperation between the two countries was signed on 24 April 2012 during the official visit of the Brazilian Foreign Minister. The areas considered in the agreement were education, agricultural research, social security, construction and investment - particularly in renewable energy resource management. In recognition of this, the concrete areas of collaboration and its mechanism with Brazil are in the process of design.

One step towards cementing these areas of collaboration involved the recent visit to the Brazilian Agricultural Research Corporation (Embrapa) by higher officials from the Ministry of Agriculture, Ethiopian Institute of Agricultural Research and Ethiopian Sugar Corporation. The aim was to share experience about the following approaches: research coordination and management systems; demand driven technology development; value additions; technology promotion and transfer mechanisms to different users; and approaches of capacity building in the research system. During the visit there was a focus on agro-energy research linked with biofuel research and development. A number of other areas of collaboration with Embrapa have also been identified, including genetic resources and biotechnology research, germplasm exchange, semi-arid tropical agricultural research related with irrigation and dryland agriculture, and small-scale farm mechanisation.

\section{Brazil and biofuels}

In recent exchanges with Brazil, biofuel development has been a top priority. Ethiopia is a non-oil producing country, fully dependent on imports. According to the Ethiopian Petroleum Enterprise (EPE), the sole importer of petroleum, the country's expenditure on fuel was 1.5 billion birr ( US\$81 million) annually in the early 1990s, which has increased to nearly 20 billion birr ( US\$1 billion) in recent years draining Ethiopia's hard-earned foreign currency. As a result, the country has started promoting alternative strategies. Accordingly, the Ethiopian government has developed a strategic document on biofuels development and utilisation with a target of 25 per cent ethanol blending by 2015 instead of the current 5 per cent (MoME 2008). This strategy has the twin objectives of both achieving energy security via diversifying the energy sources in the country, and lowering exposure to the price volatility in international oil markets. The strategy justifies the economic viability of biofuel development in Ethiopia 
by saving the scarce foreign exchange through import substitution, as well as the generation of jobs, rural development and foreign exchange earnings from export of biofuels and accessing funds through carbon trading (Alebachew 2009).

In this regard, the biofuel sector's development in Brazil is considered an excellent model; especially the sugar industry based development of ethanol production. Accordingly, the core content of the recently signed agreement between the two countries is centred on the promotion of renewable energy resource management - especially biofuels - through technical cooperation in education, agricultural research, social security, construction and investment. So far, only one private Brazilian sugar company, BDFC Ethiopia, is registered in Ethiopia (since 2007) to erect a sugar factory, including cane plantations, at Jawi in Awi Zone, Amhara Regional State.

\section{Technical cooperation with China}

The technical cooperation between China and Ethiopia has a long history dating back to the official establishment of diplomatic relations in 1970. Normally, it has been framed through cooperation agreements that have been updated several times. The current cooperation is based on the economic and technological cooperation agreements signed between the two countries on 18 December 2006 and amended on 20 March 2007. This has resulted in two concrete agricultural development related agreements: (i) the agreement to construct an Ethiopia-China Agricultural Technology Demonstration centre in Ethiopia, signed 30 May 2008; and (ii) the agreement for a provision of Chinese instructors on agricultural technical vocational education and training (ATVET) to Ethiopia.

\section{Ethiopia-China Agricultural Technology Demonstration centre}

The centre will cost RMB 40 million ( US\$6.4 million) as a non-reimbursable assistance project under the Economic and Technological Cooperation Agreements signed in 2006 and 2007, respectively. The main purpose of establishing the centre is to promote transfer of physical agricultural technologies and knowledge from China along with ensuring local capacity building through demonstration and training (MoA 2009).

The centre is established on 52 ha of land, and its overall design shows that it will use 5 ha for offices and training facilities, 3 ha for experimentation, 31 ha for crop technology demonstration, 3 ha for animal raising and demonstration, 2 ha for fish ponds, 2 ha of edible fungi demonstration garden, 2 ha for postharvest treatment and technology demonstration, and the remaining 4 ha will be for road, water channels, walls, and fences, etc. This indicates that the centre will integrate all subsectors of agriculture.

According to the agreement, the Chinese side took the following responsibilities:

- Design and construction of the centre, based on the design regulations and technical specification of China for such a purpose.

- Management and operation of the demonstration centre for the three years following completion of the civil engineering works.

- Provision and introduction of high value/high quality crop varieties.

- Testing and demonstration of advanced agricultural technologies.

- Provision of technological training.

- Provision of management and operational experiences to relevant Ethiopian staff.

- Closely working with the Ethiopian counterpart following handover of the centre to ensure its sustainable development. 
As of November 2012, 14 Chinese experts have arrived to make the centre functional, and it is expected that training programmes for the agricultural extension personnel and farmers will commence in time for the 2013 production season.

\section{Chinese technical and vocational education instructors}

This is based on a specific agreement signed between Ethiopia and China which has been under implementation since 2001. The main objective of this agreement was to send Chinese agricultural TVET instructors to Ethiopia to provide practical training within the agricultural TVET system. Each year, the agreement is renewed following the Ethiopian fiscal year. For example, the agreement for 2011/12 indicates that 16 Chinese instructors were deployed in Ethiopian agricultural TVETs. According to the agreement, the selection of relevant instructors is the responsibility of China's MoA, whilst the other costs of the programme are covered by the MoA of Ethiopia. The professional backgrounds of the instructors for the 2011-12 academic year included agronomy, plant protection, horticulture, fresh water aquaculture, livestock, sericulture, and veterinary science. Their educational levels were at that of MSc. (seven instructors) and BSc. (nine instructors). The average work experience of the instructors in this group was approximately 20 years (MoA 2010).

In Ethiopia there are 25 agricultural TVET places across the different regions. Their main role is to produce agricultural extension workers, with relevant diplomas, to become frontline development agents working closely with farmers. Figures indicate that in 2012 there were close to 60,000 development agents in the country undertaking extension work. The request for instructors from China aims to facilitate knowledge and skill transfer directly to farmers through well trained development agents.

\section{Private investment}

Linked with technical cooperation, the Ethiopian government is also promoting investment possibilities in the country.

There are high expectations of Brazilian investment in the sugar industry, linked to the promotion of biofuel (see above). The invitation by the Brazilian Foreign Minster (Mr Antonio Partiota) to the then Prime Minister, Meles Zelawi, to take part in the Rio Plus 20 Conference was expected to culminate in a detailed discussion and agreement to promote such investment, however, the visit was not realised.

Chinese investments are growing in a number of sectors, including agriculture. The Ethio-China relationship is guided by the Ministerial Conference of the Forum on China-Africa Cooperation and the different bilateral agreements between the two states. The relationship is reinforced by regular visits of state officials to China, including at the highest levels. High profile Chinese visits to Ethiopia have also helped cement the relationship, with Ethiopia seen as a preferred destination for investment.

Table 1 present the current agriculture related investments from China and Brazil with permits from the Ethiopian Investment Agency (EIA). Overall, the MoA data on foreign agricultural investments show that China and Brazil do not take centre stage. Of the total 118 agriculture related investments, 20 per cent are from the USA, 18 per cent are from foreigners with Ethiopian origin (diaspora), 15 per cent are European, 8 per cent are Israeli, 8 per cent are joint ventures, 7 per cent are Saudi, and the remaining 14 per cent is from other countries, including China and Brazil.

The total number of registered investments by China since 2008 is 32, of which 18 are in the area of vegetable farming; four are in edible oil production and processing (including a major investment in palm oil plantation with about 33 thousand ha of land), three companies are licensed in sugar cane production 
and processing, and three have received permits to operate in pig farming and processing. The other permits are approved for poultry farming (two), mushroom farming (one), and a rubber plantation (one), with about 30,000 ha. Similar findings were reported by Brautigam and Tang (2012) that Chinese farming investment is far smaller, at present, than generally believed, though Chinese engagement in agriculture and rural development in Ethiopia is longstanding.

With the exception of investments in government priority areas such as palm oil, sugar cane and rubber plantations, Chinese agriculture related investments are generally integrated, and linked with other investments in order to promote vertical integration. For example, most of the vegetable, pig and poultry farms are mainly targeted to supply local Chinese restaurants/hotels and/or other international hotels.

Registered Brazilian investments currently number only two (Table 2), although the expectation is that biofuel and sugarcane investments will increase substantially in the coming years. 
Table 1 Current status of Chinese and Brazilian agricultural investment in Ethiopia

\begin{tabular}{|c|c|c|c|c|c|}
\hline Region & Investor & Area of Investment & $\begin{array}{l}\text { Year of } \\
\text { permit }\end{array}$ & $\begin{array}{l}\text { Capital ('000 } \\
\text { birr) }\end{array}$ & Area (ha) \\
\hline \multirow[t]{3}{*}{ Amhara } & Li Youqin & Production of Sesame, Cotton, Peanut, Maize \& Wheat & 2008 & 8,800 & NA \\
\hline & Sino Farm PLC & Production of Rice \& Sesame & 2009 & 2,000 & 100.00 \\
\hline & Cao Junhan & Oil Seeds and Sugarcane Production and Processing & 2011 & 65,000 & NA \\
\hline \multirow[t]{2}{*}{ Addis Ababa } & Li Xin & Production of Vegetable & 2009 & 2,860 & 1.50 \\
\hline & MA Weiguang & Vegetable Farming & 2010 & 2,000 & \\
\hline \multirow[t]{21}{*}{ Oromiya } & Bo Wenling & Farming \& Processing of Sesame & 2008 & 1,000 & 0.10 \\
\hline & Xinyue $\mathrm{Wu}$ & Farming of Oil Seeds for Export & 2008 & 2,000 & 3.50 \\
\hline & Jin Xin & Horticulture Crops \& Improved Seeds Production & 2009 & 5,871 & 50.00 \\
\hline & Jiang Xuefang & $\begin{array}{l}\text { Production of Maize, Soya bean \& Oil Crops, Pig Farming \& } \\
\text { Processing of Pig Meat }\end{array}$ & 2009 & 4,000 & 50.00 \\
\hline & Zhonglian Ke & Farming of Vegetables & 2009 & 3,000 & 2.00 \\
\hline & Xiuhai Zhang & Farming of Vegetable & 2009 & 3,000 & 2.00 \\
\hline & Ma Wanbing & Production of Vegetables & 2009 & 3,000 & 5.00 \\
\hline & Xiang Xu & Production of Vegetables \& Fruits & 2009 & 3,500 & NA \\
\hline & $\begin{array}{l}\text { Jintian Agricultural } \\
\text { Ecology Zone PLC }\end{array}$ & Production \& Processing of Vegetables, Fruit \& Cereal Crops & 2009 & 6,000 & 100.00 \\
\hline & Min Lu & Farming of Vegetables & 2009 & 2,500 & 3.00 \\
\hline & Yiling Wang & Farming of Vegetables & 2009 & 2,500 & 1.50 \\
\hline & Fenghua Li & Farming of Vegetables & 2009 & 3,500 & .50 \\
\hline & Chenliang Guo & Farming of Vegetables \& Flower & 2009 & 7,100 & NA \\
\hline & Quan Guoxing & Vegetable Farming & 2009 & 2,580 & 0.10 \\
\hline & Ni Erming & Poultry \& Crop (Wheat \& Corn) Farming & 2009 & 15,000 & 1.50 \\
\hline & Xiong Jia & Plantation of Sugar Cane \& Sugar Factory & 2009 & 16,000 & NA \\
\hline & Shuqing Li & Pig farm and pork processing & 2010 & 10,000 & NA \\
\hline & Qiliang Wang & Vegetable farm & 2010 & 6,000 & 20.00 \\
\hline & Shoulong Gao & Breeding, fattening and processing of pig & 2010 & 8,000 & NA \\
\hline & Shuhe Hua & Vegetable Farming & 2010 & 6,000 & 10.00 \\
\hline & Wei Shen & Farming of Fruits and Vegetables & 2012 & 16,700 & NA \\
\hline SNNPR & Boleyn Industry (ET) PLC & Rubber Plantation & 2008 & 30,000 & 100,000 \\
\hline
\end{tabular}




\begin{tabular}{|c|c|c|c|c|c|}
\hline Region & Investor & Area of Investment & $\begin{array}{l}\text { Year of } \\
\text { permit }\end{array}$ & $\begin{array}{c}\text { Capital ('000 } \\
\text { birr) }\end{array}$ & Area (ha) \\
\hline & $\begin{array}{l}\text { LIM SLOW JIN ESTATE } \\
\text { SDN. BHD (Ethiopia } \\
\text { branch) }\end{array}$ & Integrated palm tree plantation and production of palm oil & 2010 & $3,761.23$ & 31,300 \\
\hline & $\begin{array}{l}\text { Joy River Meat Production } \\
\text { PLC }\end{array}$ & $\begin{array}{l}\text { Poultry Farming and Cattle Rising, Fattening and Meat } \\
\text { Processing for Local and Export Market }\end{array}$ & 2010 & 1,680 & 9.70 \\
\hline \multirow[t]{3}{*}{ Multi-regional } & Chen Chuanbing & Farming Vegetables, Fruit and Poultry & 2007 & 1,000 & 1.00 \\
\hline & $\begin{array}{l}\text { E.C Vegetables \& Fruit } \\
\text { Farm PLC }\end{array}$ & Production of Vegetables, Strawberry, Grapes, Corn \& Wheat & 2008 & 10,000 & 1,000 \\
\hline & $\begin{array}{l}\text { Ethiopia Shengda } \\
\text { Mushroom Technology } \\
\text { PLC }\end{array}$ & Farming of Mushrooms & 2009 & 1,500 & 0.50 \\
\hline
\end{tabular}

Source Ethiopian Investment Agency 2012

Table 2 Current status of Brazilian agricultural investment in Ethiopia

\begin{tabular}{|c|c|c|c|c|c|}
\hline Region & Investor & Area of Investment & $\begin{array}{l}\text { Year of } \\
\text { permit }\end{array}$ & $\begin{array}{l}\text { Capital ('000 } \\
\text { birr) }\end{array}$ & Area (ha) \\
\hline Oromiya & Tamar Farm PLC & Farming of Fruits, Grain, Sweet Pepper and Corn & 2008 & 20,000 & 1000 \\
\hline Multi-regional & $\begin{array}{l}\text { BDFC Ethiopia Industry } \\
\text { PLC }\end{array}$ & Coffee and Sugar Cane Farming and Processing & 2007 & 3,000 & NA \\
\hline
\end{tabular}

Source Ethiopian Investment Agency 2012 


\section{Conclusion}

The Ethiopian state has been heavily involved in facilitating engagement with China and Brazil, as well as other 'rising powers', as a complement to Western donor support. This has been through experience sharing in public governance, technical cooperation, and attraction of private investments.

In terms of experience sharing in public governance, both China and Brazil play an important role. Notably, they were also both bench-marked as models during the recent 'Business Process Reengineering' undertaken in all public institutions which sought to make the public service more efficient and accountable.

The cooperation with Brazil, still in the making, is expected to focus on the development of renewable energy, particularly the biofuel sector, as a way to reduce Ethiopia's dependence on imported petroleum. Therefore, the technical cooperation and attraction of investment from Brazil is geared towards this sector. Meanwhile, the technical cooperation with China is much more related to agricultural technology and knowledge transfer through collaboration in the establishment of a technology demonstration centre and the deployment of Chinese agricultural instructors.

The Ethiopian state takes a strategic approach to such engagements, focusing on particular sectors, and cultivating relationships on multiple levels, from a focus on technical exchange and technology transfer to administrative and operational reform to political relations. Currently Western donors and new emerging development cooperation partners are dealt with separately. This again serves the Ethiopian state well, allowing a portfolio of support to be developed, and avoiding a standard set of conditionalities.

With a vision of a 'developmental state', Ethiopia has been highly successful in mobilising, channelling and focusing external aid and investment towards developmental ends, avoiding the trap of the aid 'resource curse', and associated economic and political distortion and corruption, which so many aid dependent countries have fallen foul of. Exerting a strong form of 'African agency' (cf. Brown 2012) is Ethiopia's hallmark, and so far it seems to be delivering success, at least in terms of aggregate economic growth. 


\section{References}

Alebachew, A. (2009) 'Potential Social and Economical Impacts of Agro-Fuels Development in Ethiopia and the Need for Social Standards', in Proceedings of International Conference on the Status of Biofuel Development and Uses in Ethiopia, 21-28 October 2008, Addis Ababa: Faculty of Science, Addis Ababa University, 66 - 118

Altenberg, T. (2010) 'Industrial Policy in Ethiopia', Discussion Paper 2/2010, Bonn: German Development Institute

Booth, D. (2011) 'Introduction: Working with the Grain? The Africa Power and Politics Programme' IDS Bulletin 42.2: 1-10

Brautigam, D. and Tang, X. (2012a) An Overview of Chinese Agricultural and Rural Engagement in Ethiopia, IFPRI Discussion Paper 01185, Development Strategy and Governance Division, Washington, DC: International Food Policy Research Institute www.ifpri.org/sites/default/files/publications/ifpridp01185.pdf (accessed 2 April 2013)

Brown, W. (2012) 'A Question of Agency: Africa in International Politics', Third World Quarterly 33.10: $1889-1908$

Gebreyesus, M. and Lizuka, M. (2010) Experimentation and Coordination as Industrial Policy: Examples from Ethiopia and Chile, UN-WIDER: Helsinki

Geiger, M. and Goh, C. (2012) Ethiopia Economic Update: Overcoming Inflation, Raising Competitiveness, Washington DC: World Bank

GDPRD (Global Donor Platform for Rural Development) (2009) Joint Donor Principles for Agriculture and Rural Development Programmes: Incentives for Change, Bonn: Global Donor Platform for Rural Development, c/o Federal Ministry for Economic Cooperation and Development (BMZ)

Kelsall, T. (2013) Business, Politics and the State in Africa: Challenging the Orthodoxies on Growth and Transformation, London: Zed Press

Lavers, T. (2012a) "“Land Grab” as Development Strategy? The Political Economy of Agricultural Investment in Ethiopia', Journal of Peasant Studies 39.1: 105-132

Lavers, T. (2012b) 'Patterns of Agrarian Transformation in Ethiopia: State-Mediated Commercialisation and the "land grab", Journal of Peasant Studies 39.3-4: 795-822

Mkandawire, T. (2001) 'Thinking about Developmental States in Africa' Cambridge Journal of Economics 25.3: 289-314

MoA (Ministry of Agriculture) (2009) Agreement on Design-Build Contract of Ethiopia-China Agricultural Technology Demonstration Center, Addis Ababa, Ethiopia: Ministry of Agriculture

MoA (Ministry of Agriculture) (2010) Agreement Between the Ministry of Agriculture of the Federal Democratic Republic of Ethiopia and the Ministry of Agriculture of the People's Republic of China for Providing Chinese Instructors on Agricultural Technical Vocational Education and Training to the Federal Demographic Republic of Ethiopia, Addis Ababa, Ethiopia: Ministry of Agriculture

MoA (Ministry of Agriculture) (2013) Rural Economic Development and Food Security Sector Working Group (RED\&FS SWG), Ministry of Agriculture www.moa-redfs.gov.et/node/1 (accessed 26 March 2013) 
MoFED (Ministry of Finance and Economic Development) (2010) Growth and Transformation Plan (GTP) 2010/11-2014/15, Addis Ababa, Ethiopia: Ministry of Finance and Economic Development

MoFED (Ministry of Finance and Economic Development) (2005) 'Ethiopia Country Paper on Harmonization and Alignment', paper prepared and presented for the High Level Forum Paris, 28 February - 2 March 2005, Addis Ababa, Ethiopia: Multilateral Cooperation Department of the Ministry of Finance and Economic Development

Mohan, G. and Power, M. (2008) 'New African Choices? The Politics of Chinese Involvement in Africa and the Changing Architecture of Development', Review of African Political 35.115: 23-42

Mohan, G. and Lampert, B. (2013) 'Negotiating China: Reinserting African Agency into China-Africa Relations', African Affairs 112.446: 92-110

MoME (Ministry of Mines and Energy) (2008) 'Ethiopian Biofuels Development and Utilization Strategy', Addis Ababa, Ethiopia: Ministry of Mines and Energy, the Federal Democratic Republic of Ethiopia

NBE (National Bank of Ethiopia) (2011) Annual Report of the National Bank of Ethiopia - 2010/11 fiscal Year. National Bank of Ethiopia, Addis Ababa, Ethiopia: National Bank of Ethiopia

Vaughan, S. and Gebremichael, M. (2011) 'Rethinking Business and Politics in Ethiopia: The Role of EFFORT', Research Report 2, Africa Power and Politics Programme: London

\footnotetext{
${ }^{1}$ Global Humanitarian Assistance. Ethiopia Key Figures www.globalhumanitarianassistance.org/countryprofile/ethiopia (accessed 8 March 2013)

${ }^{2}$ World Bank Data. African Development Indicators: Ethiopia

http://databank.worldbank.org/data/views/reports/tableview.aspx (accessed 8 March 2013)
} 